\title{
Study on the nutritive value of dextrin as a carbohydrate source for pigs weaned at 21 days of age*
}

\author{
C.H. Lee ${ }^{2}$, Y.K. Han ${ }^{3}$, K.U. Lee ${ }^{4}$, J.D. Kim, W.T. Cho, T.G. Ko \\ and In K. Han ${ }^{1}$
}

\author{
Department of Animal Science and Technology, \\ College of Agriculture and Life Sciences. \\ Seoul National University \\ Siweon 44/-744. Korea
}

(Received 3 January 2000; accepted 4 October 2000)

\begin{abstract}
Two experiments were conducted to compare the nutritive value of dextrin to that of various carbohydrate sources and to determine the optimal incorporation ratio with lactose for pigs weaned at 21 days of age. In each experiment. eighty pigs (BW $6.43 \pm 0.18 \mathrm{~kg}$ in experiment 1 and $6.93 \pm 0.19$ $\mathrm{kg}$ in 2) were used as an experimental unit and allotted to 20 groups (4 pigs/group, 5 groups/ treatment) using a completely randomized block design. Each group was assigned to one of 5 dietary treatments. Dextrin (control), maize starch and 3 different sources of sugar (lactose, glucose. and sucrose) composed 5 dietary treatments for experiment 1. Five 5 graded lactose:glucose ratios (100:0, 75:25, 50:50, 25:75 and $0: 100$, diet $A, B, C, D$ and $E$, respectively) were used as the treatments in experiment 2 . In experiment 1 , pigs fed the diet containing maize starch showed the lowest $(P<0.05)$ average daily gain $(A D G)$ and average daily feed intake $(\Lambda D F I)$. During the second week. $\Lambda D G$ improved $(\mathrm{P}<0.05)$ for the pigs fed diets containing dextrin and 3 different
\end{abstract}

* This study was funded by MAF-SGRP (Ministry of Agriculture and Forestry-Special Grant Research Program) in Korea and is a part of the Ph.D. Dissertation of C.H. Lee under the direction of Dr. In K. Han at Seoul National University, Korca

I Corresponding author

2 Present address: E.K. Intcrnational, Inc., Korea

3 Jeil Fced Mill Co., Ltd., Korea

${ }^{4}$ National Livestock Cooperatives Federation, Korca 
sources of sugar (lactosc, glucose and sucrose) compared to pigs fed maize starch diets. For the third week after weaning, pigs fed diets with maize starch, lactose, glucose and sucrose had improved ADFI compared with pigs fed the dextrin dict $(\mathrm{P}<0.05)$. Overall, there were no significant differences in ADG and ADFI among treatments. However, pigs fed the dextrin diet had improved feed conversion ratio $(F C R)$ compared with pigs fed other diets $(P<0.05)$. During the initial $14 \mathrm{~d}$ postweaning (phase I), no significant differences were found in digestibilities of gross energy (GE), dry matter (DM), crude protein (CP) and crude ash ( $C A$ ) among treatments. During the third week postweaning (phase II), the digestibilities of GE and $\mathrm{CP}$ of pigs fed the diet containing sucrose were higher than those of the other treatments. In experiment 2, overall. no significant differences were found in $\triangle D G, \triangle D F I$ and FCR. During the initial $14 \mathrm{~d}$ postweaning (phase 1 ), no significant differences were found in nutrient digestibilities except for gross energy (GE) digestibility. GE digestibility obtained from diet $A$ was greater $(P<0.05)$ than that from diet $D$, while those for diets B, C and E were intermediate.

KEY WORDS: weaned pigs, dextrin, maize starch, lactose, glucose, sucrose, growth performance

\section{INTRODUCTION}

Nutritional variations among the carbohydrates have been reported in different species by many investigators. In the pig, however, there is relatively little data showing the effect of various carbohydrates in the diet.

In practice, lactose and dried whey are the most common carbohydrate sources for baby pigs. However, these milk-based carbohydrate sources are usually much more costly than other carbohydrate sources. Since modern baby pig diets contain highly digestible ingredients, the value of carbohydrate sources should be re-evaluated. Sucrose, or ordinary table sugar, long has been used extensively by the commercial fecd industry to give a sweet flavour and is proposed as an energy source and appetite enhancer to pig starter diets (Mavromichalis et al.. 1998). The volatile price of this commodity in recent years has led to the suggestion that consideration should be given to alternatives to sucrose. Dextrin, dextrose or glucose monohydrate are logical carbohydrates to consider. Dextrins or dextrose can be prepared casily from starch digestion. They are shorter chains of glucose molecules, but with no set number of glucose units per molecule (Ensminger et al., 1983). Eventually, dextrin or dextrose is split into glucose units, readily absorbed in the small intestine and metabolized by the pig. Hedonic preference tests conducted with human subjects generally rank dextrin only slightly below sucrose in sweetness (Chapple et al., 1981; Ensminger et al., 1983). Becker et al. (1954a) suggested that one-weck-old pigs have survived when fed diets containing dextrin or maize starch. Mahan and Newton (1993) reported that dextrose was utilized as well as lactose by 3-or 4-week-old piglets. The feeding and management regimen employed may underlic the limited and inconsistent infor- 
mation regarding the age at which the baby pig can utilize dextrin and other carbohydrate sources (Manners and Stevens, 1972). Thus, the present study was conducted to compare different carbohydrate sources (dextrin, maize starch, lactose, sucrose and glucose) and to determine the optimal lactose:dextrin incorporation ratio for pigs weaned at 21 days of age.

\section{MATERIAL AND METHODS}

One hundred and sixty, three-way crossbreed (Landrace x Large White $x$ Duroc) barrows weaned at 21 days of age were used for two experiments. At 21 days of age, pigs averaging $6.43 \pm 0.18$ and $6.93 \pm 0.19 \mathrm{~kg}$ body weight were allocated in a completely randomized block design to experiment 1 and 2, eighty each. Treatments were dextrin, maize starch, lactose, glucose and sucrose for Expcriment 1, and 100:0 (A), 75:25 (B), 50:50 (C), 25:75 (D) and 0:100 (E) acoording to 5 graded levels of lactose:dextrin ratio. Each treatment had 4 replicates with 4 pigs per replicate.

During phase I ( 0 to $14 \mathrm{~d}$ post-weaning), all pigs were fed with high nutrient density diets (Tables 1 and 3 for experiments 1 and 2, respectively). The phase I diets were formulated to contain $3,400 \mathrm{kcal} \mathrm{ME} / \mathrm{kg}, 1.65 \%$ lysine (Jin et al., 1998b). Phase II ( 15 to $21 \mathrm{~d}$ postwcaning) diets (Tables 2 and 4 for experiment 1 and 2. respectively) were formulated to contain $3,400 \mathrm{kcal} \mathrm{ME} / \mathrm{kg}, 1.50 \%$ lysine with methionine to get the optimal inter-amino acid ratios suggested by Chung and Baker (1992), Ca 0.9\% and P $0.8 \%$.

The pigs were kept in concrete-floored pens, and feed and water were given ad libitum during the entire experimental period of 3 wecks. The temperature was maintained in the range of 26 to $30^{\circ} \mathrm{C}$ throughout the experimental period. Weight gain and feed intake were measured weekly.

For determining the nutrient digestibilities of experimental diets, pigs were fed diets containing $0.20 \% \mathrm{Cr}_{2} \mathrm{O}_{3}$ during the experimental period and faeces were collected three times $(08: 00,14: 00,20: 00)$ a day after four days of adjustment period. Faecal samples were dried in an air-forced drying oven at $60^{\circ} \mathrm{C}$ for $72 \mathrm{~h}$ and ground in a Wiley mill through a $1 \mathrm{~mm}$ mesh screen for chemical analyses.

Feed and faecal samples were analyzed for proximate analysis and mineral composition by AOAC methods (1990). Chromium was measured using an atomic absorption spectrophotometer (Shimadzu, AA6145F, Japan). For energy utilisation, energy values of feed and facces were measured by an adiabatic oxygen bomb calorimeter (Model 1241, Parr Instrument Co., Molin, IL.).

Treatment means were compared by the use of the GLM procedure of the SAS package (1985), and the Duncan's multiple range test (Duncan, 1955). 
TABLE 1

Formula and chemical composition of experimental diets in phase I, Experiment 1

\begin{tabular}{|c|c|c|c|c|c|}
\hline Treatments & Dextrin & Maize starch & Lactose & Glucose & Sucrose \\
\hline \multicolumn{6}{|l|}{ Ingredients, $\%$; as fed basis } \\
\hline maize & 13.91 & 13.91 & 13.91 & 13.91 & 13.91 \\
\hline soyabean meal (CP 44\%) & 15.00 & 15.00 & 15.00 & 15.00 & 15.00 \\
\hline spay dried plasma protein & 5.15 & 5.15 & 5.15 & 5.15 & 5.15 \\
\hline fish mea! (CP 65\%) & 5.00 & 5.00 & 5.00 & 5.00 & 5.00 \\
\hline dried porcine soluble & 6.00 & 6.00 & 6.00 & 6.00 & 6.00 \\
\hline dextrin & 20.00 & - & - & - & - \\
\hline maize starch & - & 20.00 & - & - & - \\
\hline lactose & - & - & 20.00 & - & - \\
\hline glucose & - & - & - & 20.00 & - \\
\hline sucrose & - & - & - & - & 20.00 \\
\hline dried skim milk & 28.00 & 28.00 & 28.00 & 28.00 & 28.00 \\
\hline soya oil & 4.00 & 4.00 & 4.00 & 4.00 & 4.00 \\
\hline monocalcium phosphate & 0.98 & 0.98 & 0.98 & 0.98 & 0.98 \\
\hline limestone & 0.60 & 0.60 & 0.60 & 0.60 & 0.60 \\
\hline vitamin mixture & 0.20 & 0.20 & 0.20 & 0.20 & 0.20 \\
\hline mineral mixture ${ }^{\prime}$ & 0.30 & 0.30 & 0.30 & 0.30 & 0.30 \\
\hline salt & 0.30 & 0.30 & 0.30 & 0.30 & 0.30 \\
\hline antibiotics ${ }^{2}$ & 0.05 & 0.05 & 0.05 & 0.05 & 0.05 \\
\hline lysine- $\mathrm{HCl}$ & 0.06 & 0.06 & 0.06 & 0.06 & 0.06 \\
\hline DL-methionine $(50 \%)$ & 0.25 & 0.25 & 0.25 & 0.25 & 0.25 \\
\hline $\mathrm{Cr}_{2} \mathrm{O}_{3}$ & 0.20 & 0.20 & 0.20 & 0.20 & 0.20 \\
\hline \multicolumn{6}{|l|}{ Chemical composition $^{3}$} \\
\hline crude protein, $\%$ & 23.01 & 23.01 & 23.01 & 23.01 & 23.01 \\
\hline $\mathrm{Ca}, \%$ & 0.90 & 0.90 & 0.90 & 0.90 & 0.90 \\
\hline $\mathrm{P}, \%$ & 0.80 & 0.80 & 0.80 & 0.80 & 0.80 \\
\hline lysine, \% & 1.65 & 1.65 & 1.65 & 1.65 & 1.65 \\
\hline $\mathrm{ME}, \mathrm{Mcal} / \mathrm{kg}$ & 3.4 & 3.4 & 3.4 & 3.4 & 3.4 \\
\hline
\end{tabular}

' provided the followings by per kg vitamin and mineral mixture respectively: vit. A, 2000,000 IU; vit. $\mathrm{D}_{3}, 400,000 \mathrm{IU}$; vit. E, $250 \mathrm{IU}$; vit. $\mathrm{K}_{3}, 200 \mathrm{mg}$; vit. $\mathrm{B}_{1}, 20 \mathrm{mg}$; vit. $\mathrm{B}_{2}, 700 \mathrm{mg}$; pantothenic acid, 3,000 mg; choline chloride, 30,000 mg; niacin, $8,000 \mathrm{mg}$; vit. $\mathrm{B}_{12}, 13 \mathrm{mg}$; $\mathrm{Mn}, 12,000 \mathrm{mg}$; $\mathrm{Zn}$, 15,000 mg; Co, $100 \mathrm{mg}$; Cu, $500 \mathrm{mg}$; Fe, 4,000 mg; folic acid, $40 \mathrm{mg}$; BHT, 5,000 mg, Mg, $200 \mathrm{mg}$; I, $250 \mathrm{mg}$

2 Avilamycin

${ }^{3}$ calculated value 
TABLE 2

Formula and chemical composition of experimental diets in phase II, Experiment 1

\begin{tabular}{|c|c|c|c|c|c|}
\hline Treatments & Dextrin & Maize starch & Lactose & Glucose & Sucrose \\
\hline \multicolumn{6}{|l|}{ Ingredients (\%; as fed basis) } \\
\hline maize & 24.84 & 24.84 & 24.84 & 24.84 & 24.84 \\
\hline soyabean meal (CP 44\%) & 16.28 & 16.28 & 16.28 & 16.28 & 16.28 \\
\hline spray dried plasma protein & 3.80 & 3.80 & 3.80 & 3.80 & 3.80 \\
\hline fish meal (CP 65\%) & 3.80 & 3.80 & 3.80 & 3.80 & 3.80 \\
\hline dried porcine soluble & 5.00 & 5.00 & 5.00 & 5.00 & 5.00 \\
\hline dextrin & 20.00 & - & - & - & - \\
\hline maize starch & - & 20.00 & - & - & - \\
\hline lactose & - & - & 20.00 & - & - \\
\hline glucose & - & - & - & 20.00 & - \\
\hline sucrose & - & - & - & - & 20.00 \\
\hline dried skim milk & 20.00 & 20.00 & 20.00 & 20.00 & 20.00 \\
\hline soya oil & 3.20 & 3.20 & 3.20 & 3.20 & 3.20 \\
\hline monocalcium phosphate & 0.93 & 0.93 & 0.93 & 0.93 & 0.93 \\
\hline limestone & 0.65 & 0.65 & 0.65 & 0.65 & 0.65 \\
\hline vitamin mixture' & 0.20 & 0.20 & 0.20 & 0.20 & 0.20 \\
\hline mineral mixture & 0.30 & 0.30 & 0.30 & 0.30 & 0.30 \\
\hline salt & 0.30 & 0.30 & 0.30 & 0.30 & 0.30 \\
\hline antibiotics $^{2}$ & 0.05 & 0.05 & 0.05 & 0.05 & 0.05 \\
\hline lysine- $\mathrm{HCl}$ & 0.19 & 0.19 & 0.19 & 0.19 & 0.19 \\
\hline DL-methionine $(50 \%)$ & 0.26 & 0.26 & 0.26 & 0.26 & 0.26 \\
\hline $\mathrm{Cr}_{2} \mathrm{O}_{3}$ & 0.20 & 0.20 & 0.20 & 0.20 & 0.20 \\
\hline \multicolumn{6}{|l|}{ Chemical composition ${ }^{3}$} \\
\hline crude protein, $\%$ & 21.03 & 21.03 & 21.03 & 21.03 & 21.03 \\
\hline $\mathrm{Ca}, \%$ & 0.90 & 0.90 & 0.90 & 0.90 & 0.90 \\
\hline $\mathrm{P}, \%$ & 0.80 & 0.80 & 0.80 & 0.80 & 0.80 \\
\hline lysine, $\%$ & 1.50 & 1.50 & 1.50 & 1.50 & 1.50 \\
\hline $\mathrm{ME}, \mathrm{Mcal} / \mathrm{kg}$ & 3.4 & 3.4 & 3.4 & 3.4 & 3.4 \\
\hline
\end{tabular}

${ }^{1}$ provided the followings by per kg vitamin and mineral mixture respectively: vit. A, 2000,000 IU; vit. $\mathrm{D}_{3}, 400,000 \mathrm{IU}$; vit. E, $250 \mathrm{IU}$; vit. $\mathrm{K}_{3}, 200 \mathrm{mg}$; vit. $\mathrm{B}_{1}, 20 \mathrm{mg}$; vit. $\mathrm{B}_{2}, 700 \mathrm{mg}$; pantothenic acid, 3,000 mg; choline chloride, 30,000 mg; niacin, 8,000 mg; vit. $\mathrm{B}_{12}, 13 \mathrm{mg}$; Mn, 12,000 mg; Zn, 15,000 mg; Co, 100 mg; Cu, 500 mg; Fe, 4,000 mg; folic acid, 40 mg; BHT, 5, 000 mg, Mg, 200 mg; I, $250 \mathrm{mg}$

2 Avilamycin

${ }^{3}$ calculated value 
TABL.Г: 3

Formula and chemical composition of experimental diets in phase I, Experiment 2

\begin{tabular}{|c|c|c|c|c|c|}
\hline \multirow{2}{*}{ Treatments } & \multicolumn{5}{|c|}{ Lactose : Dextrin } \\
\hline & $100: 0$ & $75: 25$ & $50: 50$ & $25: 75$ & $0: 100$ \\
\hline \multicolumn{6}{|l|}{ Ingredients, $\%$; as fed basis } \\
\hline maize & 15.80 & 15.80 & 15.80 & 15.80 & 15.80 \\
\hline soyabean meal (CP $44 \%$ ) & 18.00 & 18.00 & 18.00 & 18.00 & 18.00 \\
\hline spray dried plasma protein & 5.00 & 5.00 & 5.00 & 5.00 & 5.00 \\
\hline fish meal (CP $65 \%$ ) & 5.00 & 5.00 & 5.00 & 5.00 & 5.00 \\
\hline dried porcine soluble & 6.00 & 6.00 & 6.00 & 6.00 & 6.00 \\
\hline lactose & 20.00 & 15.00 & 10.00 & 5.00 & - \\
\hline dextrin & - & 5.00 & 10.00 & 15.00 & 20.00 \\
\hline Soya oil & 4.27 & 4.27 & 4.27 & 4.27 & 4.27 \\
\hline dried skim milk & 23.00 & 23.00 & 23.00 & 23.00 & 23.00 \\
\hline monocalcium phosphate & 1.02 & 1.02 & 1.02 & 1.02 & 1.02 \\
\hline limestone & 0.66 & 0.66 & 0.66 & 0.66 & 0.66 \\
\hline vitamin mixture' & 0.20 & 0.20 & 0.20 & 0.20 & 0.20 \\
\hline mincral mixture' & 0.30 & 0.30 & 0.30 & 0.30 & 0.30 \\
\hline salt & 0.30 & 0.30 & 0.30 & 0.30 & 0.30 \\
\hline antibiotics $^{2}$ & 0.05 & 0.05 & 0.05 & 0.05 & 0.05 \\
\hline lysine- $\mathrm{HCl}$ & 0.09 & 0.09 & 0.09 & 0.09 & 0.09 \\
\hline DL-methionine $(50 \%)$ & 0.09 & 0.09 & 0.09 & 0.09 & 0.09 \\
\hline $\mathrm{Cr}_{2} \mathrm{O}_{3}$ & 0.20 & 0.20 & 0.20 & 0.20 & 0.20 \\
\hline \multicolumn{6}{|l|}{ Chemical composition ${ }^{3}$} \\
\hline crude protein. $\%$ & 23.01 & $23.0 !$ & $23.0 !$ & 23.01 & 23.01 \\
\hline Ca. $\%$ & 0.90 & 0.90 & 0.90 & 0.90 & 0.90 \\
\hline P. $\%$ & 0.80 & 0.80 & 0.80 & 0.80 & 0.80 \\
\hline lysinc, $\%$ & 1.65 & 1.65 & 1.65 & 1.65 & 1.65 \\
\hline $\mathrm{ME}, \mathrm{Mcal} / \mathrm{kg}$ & 3.4 & 3.4 & 3.4 & 3.4 & 3.4 \\
\hline
\end{tabular}

1 provided the followings by per kg vitamin and mineral mixture respectively: vit. $\Lambda, 2000,000 \mathrm{IU}$; vit. $\mathrm{D}_{r}, 400,000 \mathrm{IU}$; vit. E, $250 \mathrm{IU}$; vit. $\mathrm{K}_{3}, 200 \mathrm{mg}$; vit. $\mathrm{B}_{1}, 20 \mathrm{mg}$; vit. $\mathrm{B}_{2}, 700 \mathrm{mg}$; pantothenic acid, 3,000 mg; choline chloride, $30,000 \mathrm{mg}$; niacin, $8.000 \mathrm{mg}$; vit. $\mathrm{B}_{12}, 13 \mathrm{mg} ; \mathrm{Mn}, 12,000 \mathrm{mg} ; \mathrm{Zn}$, $15,000 \mathrm{mg} ; \mathrm{Co}, 100 \mathrm{mg} ; \mathrm{Cu}, 500 \mathrm{mg} ; \mathrm{Fc}, 4.000 \mathrm{mg} ;$ Folic acid, $40 \mathrm{mg} ; \mathrm{BHT}, 5,000 \mathrm{mg}$. Mg, $200 \mathrm{mg}$; I. $250 \mathrm{mg}$

2 Avilamycin

" calculated value 
TABLE 4

Formula and chemical composition of experimental diets in phase II. Experiment 2

\begin{tabular}{|c|c|c|c|c|c|}
\hline \multirow{2}{*}{ Trcatments } & \multicolumn{5}{|c|}{ Lactose:Dextrin } \\
\hline & $100: 0$ & $75: 25$ & $50: 50$ & $25: 75$ & $0: 100$ \\
\hline \multicolumn{6}{|l|}{ Ingredients, $\%$; as fed basis } \\
\hline nxaize & 21.60 & 21.60 & 21.60 & 21.60 & 21.60 \\
\hline soyabean meal (CP 44\%) & 16.80 & 16.80 & 16.80 & 16.80 & 16.80 \\
\hline spray dried plasma protcin & 4.00 & 4.00 & 4.00 & 4.00 & 4.00 \\
\hline fish meal (CP 65\%) & 4.00 & 4.00 & 4.00 & 4.00 & 4.00 \\
\hline dried porcine soluble & 6.00 & 6.00 & 6.00 & 6.00 & 6.00 \\
\hline lactose & 20.00 & 15.00 & 10.00 & 5.00 & - \\
\hline dextrin & - & 5.00 & 10.00 & 15.00 & 20.00 \\
\hline soya oil & 4.35 & 4.35 & 4.35 & 4.35 & 4.35 \\
\hline dried skim milk & 20.00 & 20.00 & 20.00 & 20.00 & 20.00 \\
\hline monocalcium phosphorus & 1.26 & 1.26 & 1.26 & 1.26 & 1.26 \\
\hline limestone & 0.74 & 0.74 & 0.74 & 0.74 & 0.74 \\
\hline vitamin mixture ${ }^{1}$ & 0.20 & 0.20 & 0.20 & 0.20 & 0.20 \\
\hline mineral mixturel & 0.30 & 0.30 & 0.30 & 0.30 & 0.30 \\
\hline salt & 0.30 & 0.30 & 0.30 & 0.30 & 0.30 \\
\hline antibiotics $^{2}$ & 0.05 & 0.05 & 0.05 & 0.05 & 0.05 \\
\hline lysine- $\mathrm{HCl}$ & 0.12 & 0.12 & 0.12 & 0.12 & 0.12 \\
\hline DL-methionine, $50 \%$ & 0.08 & 0.08 & 0.08 & 0.08 & 0.08 \\
\hline $\mathrm{Cr}_{2} \mathrm{O}_{1}$ & 0.20 & 0.20 & 0.20 & 0.20 & 0.20 \\
\hline \multicolumn{6}{|l|}{ Chemical composition $^{3}$} \\
\hline crude protein. $\%$ & 21.03 & 21.03 & 21.03 & 21.03 & 21.03 \\
\hline $\mathrm{Ca}, \%$ & 0.90 & 0.90 & 0.90 & 0.90 & 0.90 \\
\hline$P \%$ & 0.80 & 0.80 & 0.80 & 0.80 & 0.80 \\
\hline lysine. $\%$ & 1.50 & 1.50 & 1.50 & 1.50 & 1.50 \\
\hline $\mathrm{ME}, \mathrm{kcal} / \mathrm{kg}$ & 3.40 & 3.40 & 3.40 & 3.40 & 3.40 \\
\hline
\end{tabular}

3 provided the followings by per $\mathrm{kg}$ vitamin and mineral mixture respectively: vit. $\Lambda, 2000,000 \mathrm{IU}$; vit. $D_{;}, 400.000 \mathrm{IU}$; vit. E, $250 \mathrm{IU}$; vit. $\mathrm{K}_{2}, 200 \mathrm{mg}$ : vit. $\mathrm{B}_{1}, 20 \mathrm{mg}$; vit. $\mathrm{B}_{2}, 700 \mathrm{mg}$; pantothenic acid. $3,000 \mathrm{mg}$; choline chloride, $30,000 \mathrm{mg} ;$ niacin, $8,000 \mathrm{mg} ;$ vit. $\mathrm{B}_{12}, 13 \mathrm{mg} ; \mathrm{Mn}, 12,000 \mathrm{mg} ; \mathrm{Zn}$. $15.000 \mathrm{mg} ; \mathrm{Co}, 100 \mathrm{mg}$; Cu, $500 \mathrm{mg} ; \mathrm{Fe}, 4.000 \mathrm{mg}$ : folic acid, $40 \mathrm{mg} ; \mathrm{BHT}, 5,000 \mathrm{mg}$. Mg, $200 \mathrm{mg}$; I. $250 \mathrm{mg}$

- Avilamycin

" calculated value 


\section{RESULTS AND DISCUSSION}

\section{Experiment 1}

Growth performance

Table 5 summarizes the growth performance of pigs fed different carbohydrate sources. For the first week after weaning, ADG and ADFl improved $(\mathrm{P}<0.05)$ for the pigs fed diets containing dextrin and 3 different sources of sugar (lactose, glucose and sucrose) compared with pigs fed diet with maize starch, but differences in the feed conversion ratio (FCR) were not significant among treatments. These results suggest that baby pigs could utilize dextrin at 21 and 28 days of age with a performance similar to those of pigs fed a diet containing glucose,

TABLE 5

Growth performance of pigs fed different carbohydrate sources

\begin{tabular}{|c|c|c|c|c|c|c|}
\hline Item & Dextrin & Maize starch & Lactose & Glucose & Sucrose & $\mathrm{SE}^{\mathrm{i}}$ \\
\hline \multicolumn{7}{|l|}{ D 0 to 7} \\
\hline ADG, $g$ & $194^{a}$ & $150^{b}$ & $191^{a}$ & $185^{a}$ & $173^{3}$ & 9.35 \\
\hline ADFI, $\mathrm{g}$ & $215^{a}$ & $162^{b}$ & $222^{n}$ & $215^{a}$ & $203^{\mathrm{ab}}$ & 9.40 \\
\hline Feed/Gain & 1.12 & 1.09 & 1.16 & 1.21 & 1.20 & 0.04 \\
\hline \multicolumn{7}{|l|}{ D 8 to 14} \\
\hline ADG, $g$ & $302^{a b}$ & $258^{\mathrm{b}}$ & $298^{\text {at }}$ & $311^{a}$ & $294^{\text {ith }}$ & 9.52 \\
\hline ADFI, $\mathrm{g}$ & 386 & 367 & 383 & 410 & 396 & 11.00 \\
\hline Feed/Gain & 1.29 & 1.44 & 1.29 & 1.33 & 1.37 & 0.04 \\
\hline \multicolumn{7}{|l|}{ D 0 to 14} \\
\hline ADG. $g$ & 249 & 203 & 248 & 248 & 233 & 7.38 \\
\hline ADFI, g & 300 & 264 & 302 & 313 & 300 & 8.44 \\
\hline Feed/Gain & 1.21 & 1.32 & 1.22 & 1.28 & 1.29 & 0.03 \\
\hline \multicolumn{7}{|l|}{ D 15 to 21} \\
\hline ADG, $g$ & 442 & 446 & 481 & 468 & 446 & 12.55 \\
\hline ADFI, g & $613^{b}$ & $685^{\text {ah }}$ & $666^{\mathrm{uh}}$ & $724^{a}$ & $654^{\text {:h }}$ & 16.11 \\
\hline Feed/Gain & 1.39 & 1.54 & 1.39 & 1.58 & 1.47 & 0.03 \\
\hline \multicolumn{7}{|l|}{ D 0 to 21} \\
\hline $\mathrm{ADG}_{1} \mathrm{~g}$ & 315 & 284 & 323 & 321 & 304 & 7.71 \\
\hline $\mathrm{ADFI}, \mathrm{g}$ & 405 & 404 & 423 & 450 & 418 & 8.99 \\
\hline Feed/Gain & $1.29^{\mathrm{b}}$ & $1.44^{4}$ & $1.31^{\text {:th }}$ & $1.42^{\mathrm{ab}}$ & $1.37^{\mathrm{ah}}$ & 0.03 \\
\hline
\end{tabular}

1 pooled standard error of mean, $n=20$

a.b $\mathrm{P}<0.05$ 
sucrose and lactose. This indicates that the nutritive value of dextrin is similar to that of lactose as a carbohydrate source for growth performance in a weaner diet. This conclusion is also supported by the fact that pigs can utilize dextrin or dextrose at over 1 week of age (Becker et al., 1954a; Chapple et al., 1981; Mahan and Newton, 1993).

For the second week after weaning, ADG improved $(\mathrm{P}<0.05)$ for the pigs fed diets containing dextrin and 3 different sources of sugar (lactose, glucose and sucrose) compared with pigs fed diet with maize starch. However, ADFI and FCR were not significantly different among treatments.

For the third week after weaning. ADFI of pigs fed diets containing dextrin, maize starch, lactose and glucose were similar and lower $(\mathrm{P}<0.05)$ than that of the pigs fed the diet containing sucrose, although there were no significant differences among treatments in either ADG or FCR. The results of growth performance are in good agreement with the reports of increased sucrase activity with increasing age (Bailey et al., 1956; Walker, 1959: Dahlqvist, 1961) and of an increased rate of hydrolysis of sucrose as the pig matures (Dollar et al., 1957; Kidder et al., 1963).

During the overall period, there were no significant differences in ADG, ADFI and among treatments. Even though no significant differences were found in ADG and ADFI among treatments, the mean of ADG for pigs fed diets containing dextrin, lactose, glucose and sucrose was slightly greater than that of pigs fed diets containing maize starch. However, pigs fed the dextrin diet had improved FCR compared with pigs fed other diets $(\mathrm{P}<0.05)$.

One published report (Bayley and Carlson, 1970) has been found that deals with the use of glucose as a sweetener in starter diets. The addition of $5 \%$ glucose to a complex diet fed to weaning pigs failed to improve pig performance. This result is in agreement with this experiment. Previously, several workers (Corring et al.. 1978; Sloat et al., 1985; Hampson and Kidder, 1986) have suggested that the young pig's ability to digest the protein and carbohydrate fraction (starch) from cereal grains is not fully developed until the pig is approximately 5 week of age. Maize starch contains approximately $25 \%$ amylose and $75 \%$ amylopectin. The activity of pancreatic $\alpha$-amylase may be more effective with amylose than with amylopectin because of the greater chemical simplicity of the straight-chain carbohydrate (Riss, 1983). The activities of maltase II and III produced in the brush border cells of the small intestinal mucosa may be important avenues for amylopectin digestion (Graham et al, 1981). Pancreatic $\alpha$-amylase and maltase II and III production increase with age (Riss, 1983) but may be inadequate at 4 to 5 wecks of age to obtain maximum digestion of maize starch. Our results support their conclusion. These results indicate that maize starch as a carbohydrate source was not used as effectively as dextrin or lactose by the young weanling pig during the initial $14 \mathrm{~d}$ postweaning period. 
In the comparison of glucose with sucrose, we observed that growth performance did not differ depending on the type of supplemented sugar. This is in a good agreement with Veum and Mateo (1981) who reported that glucose was utilized as well as sucrose with similar performance by 1 -week-old piglets, but not with results of Jin et al. (1998a), which showed that the pig more efficiently utilized sucrose than glucose.

Dextrin, in summary, can be used for pigs weaned at 21 days of age as efficiently as other supplemented sugars over 3 weeks postweaning. Dextrin and all other sugar sources were better in ADG than maize starch for pigs during the first two weeks after weaning.

\section{Nutrient digestibility}

Tables 6 and 7 summarize the effects of different carbohydrate sources on proximate nutrient digestibility during phases I and II. During the initial $14 \mathrm{~d}$ postweaning (phase I), no significant differences were found in digestibilities of GE, DM, CP and CA among treatments. EE and P digestibilities were not affected by treatments, except sucrose, which showed significantly lower digestibilities of $\mathrm{EE}$ and $\mathrm{P}$. This result is not in agreement with growth performance from the present experiment. However, pigs fed the maize starch diet had considerably lower ADFI $(\mathrm{P}<0.05)$, and with a similar trend in ADG compared with pigs fed other carbohydrate sources.

During the third week postweaning (phase II), the best GE digestibility was found in pigs fed sucrose, and the worst found in pigs fed dextrin $(P<0.05)$. The results are in good agreement with several reports that increased sucrase activity with increasing age (Bailey et al., 1956; Walker, 1959; Dahlqvist, 1961) and of an increased rate of hydrolysis of sucrose as the pig maturcs (Dollar et al., 1957; Kidder et al., 1963). However, there was no significant difference in GE digestibility among maize starch, lactose and glucose. No significant differences were found in digestibilities of DM and P among treatments. Pigs fed sucrose showed the best $\mathrm{CP}$ digestibility $(\mathrm{P}<0.05)$, and worse $\mathrm{CP}$ digestibility was in pigs fed glucose and dextrin. However, there was no significant difference between glucose and dextrin. This result is in contrast with reports that pigs fed diets containing lactose had higher $(\mathrm{P}<0.05)$ apparent $\mathrm{N}$ digestibility (Sewell and West. 1965). This improvement may be caused by the high rate of sereen of lactase, the enzyme responsible for lactose degradation, present in the digestive system of the young pig (Corring et al., 1978). However, Turlington ct al. (1989) and Jin et al. (1998a) reported there were no significant differences in proximate nutricnt digestibility of pigs fed lactose, glucose, and sucrose at 17 days and 28 days of agc, respectively. Factors other than age that influence the rate of carbohydrate 
TABLE 6

Effects of different carbohydrate sources on nutrient digestibilities in phase $1, \%$

\begin{tabular}{|c|c|c|c|c|c|c|}
\hline Treatments & $\mathrm{GE}$ & DM & $\mathrm{CP}$ & $\mathrm{EE}$ & $\mathrm{CA}$ & $\mathrm{P}$ \\
\hline Dextrin & 77.91 & 90.63 & 86.25 & $74.27^{\mathrm{a}}$ & 78.53 & $65.87^{\text {ith }}$ \\
\hline Maize starch & 77.08 & 91.15 & 86.35 & $82.00^{3}$ & 79.87 & $71.52^{4}$ \\
\hline Lactosc & 80.44 & 90.35 & 87.04 & $77.15^{\prime}$ & 80.44 & $66.36^{\mathrm{uh}}$ \\
\hline Glucose & 79.01 & 91.20 & 88.74 & $75.03^{i}$ & 79.01 & $70.66^{\mathrm{th}}$ \\
\hline Sucrose & 77.10 & 90.20 & 86.78 & $61.50^{\mathrm{b}}$ & 77.09 & $63.03^{\mathrm{h}}$ \\
\hline $\mathrm{SE}^{\prime}$ & 0.32 & 0.25 & 0.39 & 1.90 & 0.72 & 1.10 \\
\hline
\end{tabular}

pooled standard error of mean, $n=20$

w.h $\mathrm{P}<0.05$

TABLE 7

Effects of different carbohydrate sources on nutrient digestibilities in phase II. $\%$

\begin{tabular}{|c|c|c|c|c|c|c|}
\hline Treatments & GE & DM & $\mathrm{CP}$ & $\mathrm{EE}$ & $\mathrm{CA}$ & $\mathrm{P}$ \\
\hline Dextrin & $87.51^{\mathrm{h}}$ & 89.29 & $83.78^{\mathrm{h}}$ & $70.22^{\mathrm{b}}$ & $71.99^{\mathrm{hc}}$ & 64.42 \\
\hline Maize starch & $88.46^{\text {atr }}$ & 89.54 & $84.59^{\text {at }}$ & $78.76^{\mathrm{a}}$ & $74.65^{\mathrm{sh}}$ & 61.72 \\
\hline Lactose & $88.02^{\mathrm{ath}}$ & 89.48 & $85.45^{\mathrm{sh}}$ & $75.35^{\mathrm{ab}}$ & $76.40^{\prime \prime}$ & 63.69 \\
\hline Glucose & $87.97^{\text {:ab }}$ & 89.30 & $84.19^{b}$ & $75.20^{\mathrm{ath}}$ & $70.89^{\circ}$ & 61.39 \\
\hline Sucrose & $89.43^{\prime \prime}$ & 90.22 & $86.21^{\prime \prime}$ & $71.34^{h}$ & $74.87^{\text {at }}$ & 64.24 \\
\hline $\mathrm{SE}^{1}$ & 0.29 & 0.16 & 0.39 & 1.33 & 0.94 & 0.64 \\
\hline
\end{tabular}

1 pooled standard error of mean, $n=20$

a.h. $\mathrm{P}<0.05$

secretion in the small intestine include: creep feeding during the suckling period (Hampson and Kidder, 1986), weaning on to dry diets or liquid diets (Deprez et al., 1987), growth factor (James et al., 1987a.b: Jaeger et al., 1990), and hormones, c.g. insulin, corticosteroids and ACTH (Sangild ct al., 1991a,b). In this trial, pigs were fed creep feed from 7 days of age, and consumed about $120 \mathrm{~g} /$ head/day of solid feed before weaning. Several studies have shown that the provision of solid feed containing complex carbohydrates to sucking pigs increases acid and pepsin secretion in the stomach (Cranwell, 1977, 1985; Cranwell and Stuart, 1984) and activity of some stomach and pancreatic enzymes (Fricnd et al., 1970; Aumaitre, 1972; Corring et al., 1978; English et al.. 1980; Sloat et al., 1985). Friend et al. (1970) and Okai et al. (1976) observed a significant increase in daily gain of pigs offered creep feeding. 


\section{Experiment 2}

\section{Growth performance}

Table 8 summarizes the effects of the dietary lactose:dextrin ratio on growth performance in weaned pigs. From d 0 to 7 postweaning, no significant differences were found in ADG, ADFI and FCR among treatments. From d 8 to 14 postweaning, the ratio of lactose:dextrin did not affect either ADG, ADFI or FCR which is in agreement with Becker et al. (1954b) and Chapple et al. (1989). From d 15 to 21 postweaning, there were no significant differences among treatments in ADG and FCR. However, ADFI increased as the lactose content in the diet increased. This response of ADFI is in good agreement with that from our previous study, experi-

TABLE 8

Effects of dietary lactose:dextrin ratio on growth performance in weaned pigs

\begin{tabular}{|c|c|c|c|c|c|c|}
\hline \multirow{2}{*}{ Treatments } & \multicolumn{5}{|c|}{ Lactose : Dextrin } & \multirow{2}{*}{$\mathrm{SE}^{\prime}$} \\
\hline & $100: 0$ & $75: 25$ & $50: 50$ & $25: 75$ & $0: 100$ & \\
\hline \multicolumn{7}{|l|}{ D 0 to 7} \\
\hline ADG, $g$ & 283 & 309 & 280 & 343 & 314 & 10.20 \\
\hline ADFI, $\mathrm{g}$ & 302 & 346 & 297 & 344 & 331 & 10.55 \\
\hline Feed/Gain & 1.07 & 1.13 & 1.08 & 1.01 & 1.05 & 0.02 \\
\hline \multicolumn{7}{|l|}{ D 8 to 14} \\
\hline ADG, g & 381 & 357 & 365 & 357 & 364 & 6.74 \\
\hline ADFI, $\mathrm{g}$ & 465 & 421 & 430 & 429 & 467 & 11.32 \\
\hline Feed/Gain & 1.22 & 1.18 & 1.18 & 1.20 & 1.28 & 0.02 \\
\hline \multicolumn{7}{|l|}{ D 0 to 14} \\
\hline ADG, $\mathrm{g}$ & 338 & 332 & 327 & 356 & 334 & 7.59 \\
\hline ADFI, $g$ & 384 & 383 & 363 & 387 & 399 & 8.75 \\
\hline Feed/Gain & 1.14 & 1.15 & 1.11 & 1.09 & 1.20 & 0.02 \\
\hline \multicolumn{7}{|l|}{ D 15 to 21} \\
\hline ADG, $\mathrm{g}$ & 456 & 442 & 449 & 394 & 373 & 12.73 \\
\hline ADFI, $g$ & $679^{a}$ & $614^{a b}$ & $630^{\mathrm{ab}}$ & $580^{\mathrm{b}}$ & $576^{\mathrm{b}}$ & 14.93 \\
\hline Feed/Gain & 1.49 & 1.40 & 1.42 & 1.49 & 1.56 & 0.03 \\
\hline \multicolumn{7}{|l|}{ D 0 to 21} \\
\hline ADG, $g$ & 381 & 368 & 362 & 349 & 355 & 6.89 \\
\hline ADFI, $\mathrm{g}$ & 482 & 460 & 452 & 451 & 458 & 9.31 \\
\hline Feed/Gain & 1.26 & 1.25 & 1.26 & 1.29 & 1.29 & 0.01 \\
\hline
\end{tabular}

pooled standard error of mean, $n=20$

a.b $\mathrm{P}<0.05$ 
ment I. During the entire period of this experiment, no significant differences were found in ADG, ADFI and FCR.

In summary, from 21 to 42 days of age all of the treatments produced equal ADG. ADFI and FCR. This experiment clearly indicates that some pigs develop a marked ability to utilize dextrin in case lactose is not adequately supplemented to diets.

\section{Nutrient digestibility}

Tables 9 and 10 summarize the effects of the lactose:dextrin ratio on nutrient digestibilities in phases I and II. During the initial $14 \mathrm{~d}$ postweaning (phase I), no significant differences were found in digestibilities of DM, EE, CA and P among treatments. These data on nutrient digestibilities are well matched with the two

TABLE 9

Effects of dietary lactose:dextrin ratio on nutrient digestibilities in phase I, \%

\begin{tabular}{|c|c|c|c|c|c|c|}
\hline Treatments & GE & DM & $\mathrm{CP}$ & $\mathrm{EE}$ & $\mathrm{C} \Lambda$ & $\mathrm{P}$ \\
\hline \multicolumn{7}{|c|}{ Lactose : Dextrin, $\%$} \\
\hline $100: 0$ & $90.23^{\mathrm{a}}$ & 90.37 & $88.05^{\prime \prime}$ & 68.49 & 75.10 & 56.28 \\
\hline $75: 25$ & $89.96^{\mathrm{sh}}$ & 90.57 & $87.68^{\text {ilb }}$ & 65.30 & 75.91 & 60.16 \\
\hline $50: 50$ & $89.63^{\text {it }}$ & 90.36 & $87.50^{\text {in }}$ & $60.6 !$ & 75.34 & 58.68 \\
\hline $25: 75$ & $88.71^{\mathrm{b}}$ & 90.01 & $86.62^{\mathrm{sh}}$ & 60.83 & 76.34 & 58.54 \\
\hline $0: 100$ & $89.37^{\mathrm{sh}}$ & 89.91 & $86.18^{\mathrm{h}}$ & 63.27 & 73.51 & 55.45 \\
\hline SE' & 0.21 & 0.13 & 0.25 & 1.17 & 0.55 & 1.09 \\
\hline
\end{tabular}

1 pooled standard error of mean. $n=20$

a.h $\mathrm{P}<0.05$

TABLE 10

Effects of dictary lactose:dextrin ratio on nutrient digestibilities in phase II, \%

\begin{tabular}{|c|c|c|c|c|c|c|}
\hline Treatments & $\mathrm{GL}$ & DM & $C P$ & EE & $\mathrm{CA}$ & $\mathrm{P}$ \\
\hline \multicolumn{7}{|c|}{ Lactose : Dextrin, $\%$} \\
\hline $100: 0$ & 87.28 & 88.23 & 82.89 & 57.58 & 71.01 & 5.3 .47 \\
\hline $75: 25$ & 87.21 & 88.14 & 82.85 & 65.00 & 69.75 & 49.34 \\
\hline $50: 50$ & 86.85 & 88.21 & 81.07 & 52.62 & 70.77 & 54.72 \\
\hline $25: 75$ & 86.73 & 88.11 & 83.25 & 66.75 & 70.26 & 50.80 \\
\hline $0: 100$ & 87.33 & 88.13 & 82.51 & 60.75 & 67.90 & 54.04 \\
\hline $\mathrm{SE}^{\prime}$ & 0.33 & 0.32 & 0.52 & 2.52 & 0.82 & 1.43 \\
\hline
\end{tabular}

1 pooled standard error of mean, $n=20$ 
reports (Chapple et al., 1981; Ensminger et al., 1983) showing that dextrin is shorter chains of glucose molecules, but no set number of glucose units per molecule and eventually, dextrin is split into glucose units, readily absorbed in the small intestine and metabolized by the pig. Other workers (Dahlqvist, 1961; Coffec, 1998) reported that dextrinase is released from the brush border of the small intestine and splits $\alpha$-limit dextrin to glucose, maltose and maltotriose. Gross energy (GE) digestibility obtaincd from diet $\mathrm{A}$ was greater $(\mathrm{P}<0.05)$ than that from diet $\mathrm{D}$, while those for diets $\mathrm{B}, \mathrm{C}$ and $\mathrm{E}$ were intermediate. This improvement may be caused, similarly as in the case of crude protein digestibility as mentioned above, by the high level of lactase (Ekstrom et al., 1975; Corring ct al., 1978; Giesting et al., 1985). The best crude protein (CP) digestibility was found in pigs fed diet A, and the worst was found in pigs fed diet E; those for diets B. C and D were intermediate. This result is supported by reports (Sewell and West, 1965) that pigs fed diets containing lactose had higher $(\mathrm{P}<0.05)$ apparent $\mathrm{N}$ digestibility.

During the third weck postweaning (phase II), there were no significant differences in any nutrient digestibilities among treatments. This may explain why pigs fed different diets showed similar growth performance from d 15 to 21 postweaning. In phase I, the GE digestibility of pigs fed diet $\mathrm{A}$ was greater $(\mathrm{P}<0.05)$ than those of other treatments, but GE digestibility was not affected by treatments in phase II. This trend can be explained by several reports (Bailey et al., 1956; Walker, 1959; Hartman et al., 1961; Manners and Stevens, 1972) showing that the specific activity of mucosal lactase in the small intestine of the pig is high at birth but begins to decline by about 2 weeks of age and 6 weeks of age is similar to the low levels normally found in mature pigs.

In conclusion, these results suggest that all of the treatments produced similar ADG and ADFI except for maize starch, which was inferior. These results also suggest that dextrin was utilized as effectively as lactose, sucrose, glucose and could substitute lactose in part for weanling pigs.

\section{REFERENCES}

AOAC, 1990. Official Methods of Analysis. 15th Edition. Association of Official Analytical Chemists. Washington, DC

Aumaitre A., 1972. Development of enzyme activity in the digestive tract of the suckling pig: nutritional significance and implications for weaning. World Rev. Anim. Prod. 8, 71-86

Bailey C.B., Kitts W.D., Wood A.J., 1956. The development of digestive enzyme system of the pig during its pre-weaning phase of growth. B. Intestinal lactase, sucrase and maltase. Can. J. Agr. Sci. $36,5 !-58$

Bayley H.S., Carison W.E., 1970. Comparisons of simple and complex dicts for baby pigs: Effect of form of feed and of glucose addition. J. Anim. Sci. 30, 394-401 
Becker D.E., Ullrcy D.E. Terrill S.W., 1954a. A comparison of carbohydrates in a synthetic milk diet for the baby pig. Arch. Biochem. Biophys. 48, 178-183

Becker D.E.. Ullrey D.E., Terrill S.W., Notzold R.A., 1954b. Failure of newborn pigs to utilize dietary sucrose. Science 120,345-346

Chapple R.P.. Cuaron J.A., Easter R.A., 1981. Relative efficacy of glucose and sucrose in complex pig starter diets. In: University of Illinois Cooperative Extension Service Report

Chapple R.P., Cuaron J.A., Easter R.A., 1989. Effect of glucocorticoids and limiting nursing on the carbohydrates digestive capacity and growth rate of piglets. J. Anim. Sci. 67, 2956-2973

Chung T.K., Baker D.H., 1992. Ideal amino acid pattern for 10-kilogram pigs. J. Anim. Sci. 70, 3102-3111

Corring T., Aumaitre $\Lambda$., Durand G., 1978. Development of digestive enzyme in the piglet from birth to 8 wecks. Nutr. Metab. 22, $231-243$

Cranwell P.D. 1977. Acid and pepsin secretion in young pigs reared solely by the sow or supplemented witly solid food and weaned at $21 \mathrm{~d}$. Proc. Nutr. Soc. $36,142 \Lambda$

Cranwell P.D., 1985. The development of acid and pepsin secretory capacity in the pig: effect of age and weanıng. I. Studies in anaesthetized pigs. Brit. J. Nutr. 54, 305-320

Cranwell, P. D. Stuart S.J., 1984. The effect of diet and liveweight on gastric secretion in the young pig. Proc. Aust. Soc. Anim. Prod. 15, 669-672

Dahlquist A., 1961. Intestine carbohydrates of a newborn pig. Nature 190,31-32

Deprez. P., Deroose P., van den Hende. Muylle C., Oyaert W., 1987. Liquid versus dry feeding in weaned piglets; the influence on small intestinal morphology. J. Vet. Med. B34, 254-259

Dollar A.M., Mitchell K.G.. Porter J.W.G., 1957. The utilization of carbohydrates in the young pig. Proc. Nuti: Soc. 16, xii

Duncan D.B., 1955. Multiple range and mutiple $F$ test. Biometrics 11, 1-42

Ekstrom K.E., Benevenga N.J.. Grummer R.H., 1975. Changes in the intestinal lactase activity in the small intestine of two breeds of swine from birth to 6 weeks of age. J. Nutr. 105, 1032-1038

Englisb P.R.. Robb C.M., Dias M.F.M., 1980. Evaluation of creep feeding using a highly-digestible diet for litters weaned at 4 wecks of age. Anim. Prod. 30, 496 ( $\Lambda$ bstr. 107)

Ensminger A.H., Ensminger M.E.. Konlande J.E., Robson J.R.K.. 1983. Foods and Nutrition Encyclopedia. 1st Edition. Pegus Press, Califonia (USA)

Friend D.W., Gorrill A.D.L., Macintyre T.M., 1970. Performance and proteolytic enzyme activity of the suckling piglet creep-fed at one or three weeks of age. Can. J. Anim. Sci. 50, 349-354

Giesting D.W. Easter R.A., Roe B.A., 1985. A comparison of protein and carbohydrate source of milk and plant origin for starter pigs. J. Anin. Sci. 61, Suppl. 1. 299 (Abstr.)

Graham P.1.. Mahan D.C.. Shields R.G., Jr., 1981. Effect of starter diet and length of feeding regimen on performance and digestive enzyme activity of 2 -week old weaned pigs. J. Anim. Sci. 53. 299-307

Hampson D.J.. Kidder D.E., 1986. Influence of creep feeding and weaning on brush border enzyme activities in the small intestine. Res. Vet. Sci. 40, 24-31

Hartman R.P., Hays V.W., Baker R.O., Neagle I..H., Catron D.V., 1961. Digestive enzyme development in the pig. J. Anim. Sci. 20, 114-123

Jaeger I.A., Iamar C.H. Cline T.R., Cardona C.J., 1990. Effect of orally administered epidermal growth factor on the jejunal mucosa of weaned pigs. Amer. J. Vet. Res. 51, 471-474

James P.S., Smith M.W. Tivey D.R., Wilson T.J.G., 1987a. Epidermal growth factor selectively increases maltase and sucrase activities in neonatal piglet intestine. J. Plyysiol. 393, 583-594

James P.S., Smith M.W.. Tivey D.R.. Wilson T.J.G., 1987b. Dexamethasone sclectively increases sodium-dependent alanine transport across neonatal piglet intestine. J. Physiol. 393, 569-582 
Jin C.F., Kim J.H., Moon H.K., Cho W.T., Han Y.K., Han In K., 1998a, Effects of various carbohydrate sources on the growth performance and nutrient utilization in pigs weaned at 21 days of agc. Asian-Austr. J. Anim. Sci. 11, 285-292

Jin C.F., Kim J.H., Han In K., Yeon J.U., 1998b. Optimum lactose:sucrose ratio for the pigs weaned at 21 days of age. $\Lambda$ sian- $\Lambda$ ustr. J. Anim. Sci. $11,185-191$

Jin C.F., Kim J.H., Cho W.T., Kwon K., Han In K., 1998c. Lysine requirements of piglets. AsianAustr. J. Anim. Sci. 11, 89-96

Johnson S.R., 1949. Comparison of sugars in the purified diet of baby pigs. Fed Proc. 8. 387 (Abstr.)

Kidder D.E., Manners M. J., McCrea M.R., 1963. The digestion of sucrose by the piglet. Res. Vet. Sci. $4,131-144$

Lewis C.J., Catron D.V., Combs G.E., Jr., Ashton G.C., Culbertson C.C., 1955. Sugar in pig starters. J. Anim. Sci. 14, 1103-1115

Mahan D.C., Newton E.A.. 1993. Evaluation of feed grains with dried skim milk an added carbohydrate sources on weanling pig performance. J. Anim. Sci. 71, 3376-3382

Manners M.J. Stevens J.A.. 1972. Changes from birth to manurity in the pattern of distribution of lactase and sucrase activity in the mucosa of the small intestine in pigs. Brit. J. Nutr. 28, 113-127

Mavromichalis I., Hancock J.D., Hines R.H., DeRouchey J.M., Senne B.W., Sorrell S.P., Cao H., 1998. Sucrose and molasses in simpler or complex diets for nursery pigs. In: Swine Day 1998. Kansas University, pp. 75-81

Okai D.B., Aheme F.X., Hardin R.T., 1976. Effects of creep and starter composition on feed intake and performance of young pigs. Can. J. Anim. Sci, 56, 573-586

Riss P.M., 1983. Dynamic Biochemistry of Animal Production. Elsevier Science Publishers, Amsterdam

SAS, 1985. SAS User's Guide : Statistics, SAS Inst. Inc., Cary, NC

Sangild P.T., Cranwell P.D., Sørensen H., Mortensen K., Norén O., Wetteberg L., Sjöström II., 1991 a. Development of intestinal disaccharides, intestinal peptidases and pancreatic proteases in sucking pigs. The effect of age and ACTH treatment. In: M.W.A. Verstegen, J. Huisman, L.A. den Hartog (Editors). Digestive Physiology in Pigs. Pudoc, Wageningen, pp.73-78

Sangild P.T., Foltmann B., Cranwell P.D., 1991b. Development of gastric proteases in fetal pigs and pigs from birth to thirty six days of age. The effect of $\Lambda$ CTH. J. Develop. Physiol. 16, 229-238

Sewell R.F.. West J.P., 1965. Some effects of lactose on protein utisization in the baby pig. J. Anim. Sci. 24, 239-241

Sloat DA., Mahan D.C., Kramer D.L., 1985. Effect of pig weaning weight on postweaning body composition and digestive cnzyme development. Nutr. Rep. Int. 31, 624-634

Turlington W.H., Allee G.L., Nelssen J.L., 1989. Effects of protein and carbohydrate sources on digestibility and digesta flow rate in weaned pigs fed a high-fat, dry diet. J. Anim. Sci. 67, 23332340

Veum T.L.. Mateo J.P., 1981. Utilization of glucose, sucrose or corn starch with cascin or isolated soybean protein supplemented with amino acids by 8 -day-old pigs reared artificially. J. Anim. Sci. 53, 1027-1038

Walıltrom R.C., Hauser L.A., Libal G.W., 1974. Effects of low lactose whey, skim milk and sugar on diet palatability and performance of early weaned pigs. J. Anim. Sci. 38, 1267-1271

Walker D.M.. 1959. The development of the digestive system of the young animal. IJ. Carbohydrate enzyme development in the young pig. J. Agr. Sci. 52, 357-363 


\section{STRESZCZENIE}

\section{Wartość pokarmowa dekstryny jako źródła węglowodanów dla prosiąt odsadzonych w 21 dniu życia}

Przeprowałzono dwa doświadczenia. w których porównywano wartość pokarmową dektryny z innymi węglowodanami celem określenia optyma!nego stosunku laktoza:dekstryna, jaki można zastosować w dietach dla prosiąt odsadzonych w 2 l dniu życia. W każdym doświadczeniu, 80 prosiąt, o m.c. $6,43 \pm 0,18 \mathrm{~kg}$ w doświadczeniu 1 i $6,93 \pm 0.19 \mathrm{~kg} \mathrm{w}$ doświadczeniu 2 rozdzielono do 20 grup (4 prosięta/grupa; 5 grup/doświadczenie). stosując układ kompletnych bloków losowych. W doświadczeniu 1 dekrytynę stosowano w grupie kontrolnej, w pozostałych skrobię kukurydzianą lub jeden z 3 cukrów (laktozę, glukozç, sacharozç), w doświadczeniu 2 laktozę i dekstrynę w różnym stosunku $(100: 0,75: 25,50: 50,25: 75, \mathrm{j} 0: 100)$.

W doświadezeniu 1 prosięta 7 grupy otrzymującej skrobiç kukurydzianą pobicrały najmnicj paszy ( $\triangle \mathrm{DFI}$ ) oraz miały najniższe dzienne przyrosty (ADG: $\mathrm{P}<0,05$ ). W ciagu drugiego tygodnia doświadczenia $\Lambda D$ G prosiąt grupy kontrolnej oraz otrzymujących w diecie laktozę. glukozę lub sacharozę byly lepsze $(\mathrm{P}<0,05)$ niż prosiąt otrzymujących skrobį kukurydzianą. W trzecim tygodniu po odsadzeniu $A D F I$ przez prosięta wszystkich grup doświadczalnych były lepsze $(\mathrm{P}<0,05)$ niż przez kontrolne. W ciagu całego doświadczenia nie stwierdzono tóżnic w ADFI i ADG pomiędzy grupami, jednak wykorzystanie paszy (FCR) przez prosięta grupy kontrolnej było lepsze $(\mathrm{P}<0,05)$ niż $z$ pozostałych grup. W ciagu pierwszych 14 dni po odsadzeniu (faza I) nie stwicrdzono różnic w strawności energii brutto (GE), suchej masy (DM), białka ogólnego (CP) oraz popiołu (CA) miçdzy grupami, w trzecim tygodniu (faza II) strawność GE i CP była wyższa w grupic prosiąl otrzymujących sacharozę niż w pozostałych.

W doświadczeniu 2 nie stwierdzono różnic między grupami w $\triangle D F I, \triangle D G$, i FCR. W ciagu pierwszych 14 dni po odsadzeniu (faza l) strawnośc GE była większa $(\mathrm{P}<0.05$ ) w grupic prosiąt otrzymujących tylko laktozę niz. laktozę i dekstrynę w stosunku 25:75; wartości w pozostałych grupach byly pośrednie. 